Diterima: 27/11/2020, Direview: 17/03/2021, Diterbitkan: 30/04/2021

\title{
POTENSI EKSTRAK POLISAKARIDA LARUT AIR (PLA) DARI BIJI ASAM (Tamarindus indica L) SEBAGAI KONTROL BERAT BADAN DAN GLUKOSA DARAH
}

\section{Potential of Water-Soluble Polysaccharides from Tamarind Seed Extract as Weight and Glucose Control}

\author{
Harijono*, Aulia Azizah Syamsuri, Kiki Fibrianto, Siti Narsito Wulan, Hera Sisca Prasmita \\ Jurusan IImu dan Teknologi Pangan, FTP Universitas Brawijaya \\ Jl. Veteran, Malang 65145 \\ *Penulis Korespondensi, Email: Harijono@ub.ac.id
}

\begin{abstract}
ABSTRAK
Biji asam jawa (Tamarindus indica $\mathrm{L}$ ) merupakan salah satu potensi lokal Indonesia khususnya daerah Nusa Tenggara. Ekstrak polisakarida larut air (PLA) biji asam berperan sebagai sumber serat yang dapat mengendalikan berat badan dan glukosa darah. Tujuan penelitian yaitu untuk mengoptimasi ekstraksi PLA biji asam yang memiliki rendemen dan tingkat kelarutan yang paling baik sebagai kontrol berat badan dan glukosa darah. Proses optimasi menggunakan metode Box Behnken Design (BBD) dengan bantuan software Design Expert 10.0. Hasil optimasi yang diperoleh diverifikasi dan dilakukan pengujian potensinya terhadap berat badan dan glukosa darah. Hasil menunjukkan bahwa pemberian ekstrak PLA biji asam pada pakan tikus diet tinggi lemak selama 40 hari memiliki pengaruh signifikan terhadap kelompok kontrol negatif dan kontrol positif pada kadar glukosa darah tikus. Sehingga dapat disimpulkan pemberian ekstrak kasar PLA biji asam dapat mengendalikan kadar glukosa tikus diet tinggi lemak.
\end{abstract}

Kata Kunci: Biji asam jawa, Ekstrak kasar, Polisakarida larut air

ABSTRACT

Tamarind seed (Tamarindus indica $L$ ) is one of Indonesian's local potentials, especially in Nusa Tenggara. Water-soluble polysaccharides (PLA) of Tamarind seeds act as a source of fiber that controls weight and blood glucose level. The aim of this research is to optimize extraction of Water-soluble polysaccharides (PLA) from Tamarind seeds that have best yield and solubility as a control of weight and glucose levels. The optimized used Box Behnken Design (BBD) at Design Expert 10.0 software. The optimal result was verified and tested as a weight and blood glucose levels controller. The result shows that the intake of water-soluble polysaccharides from Tamarind seeds during 40 days was significant in glucose levels of rats. The conclusion of this research was water-soluble polysaccharides from the crude extract of tamarind seeds could reduce glucose levels of high-fat diet rats.

Keywords: Crude extract, Tamarind seeds, Water-soluble polysaccharides

\section{PENDAHULUAN}

Biji asam merupakan produk samping hasil pengolahan buah asam yang masih kurang dimanfaatkan (Azad, 2018). Mota et al (2020) melaporkan bahwa lebih dari 90\% biji asam terbuang menjadi limbah dan kurang dari $10 \%$ dimanfaatkan oleh industri non pangan. Biji asam mengandung PLA yang cukup tinggi yaitu sekitar 72\% (Alpizar-Reyes et al., 2017). PLA ini dapat menjadi sumber serat yang bersifat resisten terhadap proses pencernaan. PLA yang 
tidak tercerna dapat terikat dengan kolesterol di dalam usus sehingga kolesterol tidak akan diserap oleh darah dan dikeluarkan dari tubuh bersama feses. PLA juga dapat memperlambat penyerapan glukosa dan merangsang terjadinya fermentasi oleh mikroflora di dalam kolon (Benkeblia, 2014).

Hiperglikemia adalah penyakit metabolik kronis yang ditandai dengan kadar gula darah tinggi yang disebabkan oleh kekurangan insulin. Jika kadar glukosa darah puasa seseorang $>140 \mathrm{mg} / \mathrm{dL}$ atau kadar glukosa darah sesaat $>180 \mathrm{mg} / \mathrm{dL}$ maka dapat dikatakan hiperglikemia (Setyaningsih et al., 2015). Pengobatan hiperglikemia dapat dilakukan dengan mengkonsumsi sumber pangan yang tinggi serat. Penelitian mengenai penggunaan ekstrak kasar PLA biji asam sebagai pengganti CMC untuk pengendalian penyakit metabolik masih belum dijumpai. Penelitian ini dimaksudkan untuk mengetahui hasil optimasi ekstraksi menggunakan metode sonikasi pada beberapa tingkatan suhu sebagai perlakuan pendahuluan untuk ekstraksi PLA kasar biji asam dari beberapa tingkat pH dan ukuran partikel. Ekstrak kasar yang diperoleh selanjutnya digunakan untuk pengendalian hiperglikemia pada tikus obesitas.

\section{BAHAN DAN METODE}

\section{Bahan}

Sampel biji asam berasal dari Nusa Tenggara Timur, dan Rattus Norvegicus Strain Wistar dewasa, berat badan 200-250 gram dengan kondisi sehat yang ditandai dengan gerakannya aktif dan dibuktikan melalui surat keterangan sehat dari dokter hewan.

Alat

Cabinet dryer, ultrasonik, kandang tikus, botol minum tikus, tempat pakan tikus, alatalat untuk pembuatan pakan tikus, blood glucose test meter model AGM-2100 dengan strip glucotest GlucoDr ${ }^{\mathrm{TM}}$ No. 8 (Allmedicus)

\section{Desain Penelitian}

Penelitian ini menggunakan RAL (Rancangan Acak Lengkap) dengan 3 kelompok perlakuan dengan rincian sebagai berikut:

Kontrol Negatif (STD) : Tikus Diet Standart (AIN 93) sebagai Tikus normal

Kontrol Positif (KOL) : Tikus Diet Tinggi Lemak

Perlakuan (PLA) : Tikus Diet Tinggi Lemak + ekstrak kasar PLA biji asam yang dicampurkan dalam pakan

\section{Tahapan Penelitian}

Penelitian ini diawali dengan melakukan preparasi biji asam yang akan digunakan yaitu proses penggilingan dan pemisahan endosperm biji asam tersebut sehingga menjadi tepung biji asam, lalu dilanjutkan dengan proses pretreatment menggunakan ultrasonik dan proses ekstraksi dengan metode perebusan. Ekstrak kasar PLA biji asam yang diperoleh digunakan dalam campuran pakan tikus sebagai pengganti CMC selama 40 hari perlakuan. Lalu dilakukan pengujian kadar glukosa darah tikus pada hari ke 40.

\section{Metode Penelitian \\ Preparasi PLA biji asam}

Sebelum diekstraksi, biji asam dicuci bersih dan dijemur selama $2 \times 8$ jam lalu pengeringan dilanjutkan menggunakan lokal cabinet dryer (tegangan $220 \mathrm{~V}-240 \mathrm{~V}$ ) suhu $60 \pm 2^{\circ} \mathrm{C}$, selama 18 jam. Kemudian dihancurkan menjadi tepung biji asam menggunakan disk mill. kernel dan epidermis dipisahkan menggunakan saringan berukuran 30 mesh. Tepung biji asam yang diperoleh dikeringkan lagi menggunakan local cabinet dryer suhu $60 \pm 2^{\circ} \mathrm{C}$, selama 9 jam bertujuan untuk mengurangi kadar air pada bahan. Tepung biji asam diayak menggunakan ayakan masing masing dengan ukuran 45 mesh.

\section{Ektraksi PLA biji asam}

Masing-masing tepung biji asam yang telah diayak sebanyak $50 \mathrm{~g}$ dilarutkan kedalam $500 \mathrm{~mL}$ pelarut sesuai dengan $\mathrm{pH} 5$ atau dengan rasio 1:10, lalu di pretreatment dengan suhu 
$60^{\circ} \mathrm{C}$, selama 15 menit menggunakan ultrasonik cleaner merk skymen, model JP-010S, Volt AC $220-240 \mathrm{~V} 50 \mathrm{~Hz}$, heating power $100 \mathrm{~W}$, Frekuensi $40 \mathrm{KHz}$, kapasitas $2 \mathrm{~L}$. setelah di pretreatment, kemudian penambahan pelarut sebanyak $300 \mathrm{~mL}$ dan dilakukan perebusan menggunakan panci stainless stee/ suhu $80 \pm 2^{\circ} \mathrm{C}$ selama 5 menit. Waktu perebusan dihitung saat suhu tercapai. Hasil rebusan disaring menggunakan kain penyaring. Filtrat yang diperoleh dinetralkan menggunakan $\mathrm{NaOH} 1 \mathrm{~N}$ hingga $\mathrm{pH}$ 7, lalu dituangkan kedalam loyang yang telah dilapisi plastik dan dikeringkan menggunakan cabinet dryer suhu $55 \pm 2^{\circ} \mathrm{C}$. filtrat yang telah kering dihaluskan menggunakan blender.

\section{Prosedur Pembuatan Pakan Tikus Tinggi Lemak dan Kolesterol}

Komposisi pembuatan pakan tinggi kolesterol dengan diet basal dapat dilihat pada Tabel 1 dengan standar pakan mendekati komposisi pakan AIN 93. Setiap formula pakan diberikan kepada setiap ekor tikus pada masing-masing kelompok perlakuan sebanyak 20 gram/ekor/hari. beberapa jurnal menyebutkan bahwa pembuatan pakan tikus biasanya menggunakan 1\% kolesterol untuk dapat dikatakan tinggi kolesterol. Namun pada penelitian ini sumber kolesterol diganti menggunakan lemak hewan dan kuning telur

Tabel 1. Formula Pakan Tikus Percobaan dengan Pakan Standar Modifikasi AIN 93

\begin{tabular}{lccc}
\hline $\begin{array}{c}\text { Komposisi } \\
\text { Bahan (gram) }\end{array}$ & $\begin{array}{c}\text { Kel. Tikus Diet } \\
\text { Standar } \\
\text { Normal }\end{array}$ & $\begin{array}{c}\text { Kel. Tikus Diet } \\
\text { Tinggi Lemak } \\
\text { (KOL) }\end{array}$ & $\begin{array}{c}\text { Kel. Tikus Diet Tinggi } \\
\text { Lemak + ekstrak PLA } \\
\text { biji asam (PLA) }\end{array}$ \\
\hline Tepung Maizena & 367.45 & 336.01 & 336.01 \\
Kasein & 855.49 & 0 & 0 \\
Tepung Kuning & 0 & 400 & 400 \\
Telur & 122.3 & 111.84 & 111.84 \\
Dekstrin & 78.9 & 72.15 & 72.15 \\
Sukrosa & 0 & 124.43 & 124.43 \\
Lemak sapi & 32.77 & 34.24 & 0 \\
CMC & 0 & 32 & 0 \\
Multivitamin & 2.5 & 0 & 32 \\
Lesitin & 0 & 0 & 34.24 \\
Ekstrak kasar & & & \\
PLA biji asam & & &
\end{tabular}

1) Komposisi pakan mendekati komposisi pakan standar AIN 93

2) Diet tinggi akan : tinggi tepung kuning telur dan lemak sapi, CMC sebagai serat pangan

3) Ekstrak PLA biji asam sebagai pengganti CMC dicampurkan dalam pakan

\section{Prosedur Analisis}

Pakan yang diberikan merupakan formulasi pakan tinggi lemak berdasarkan AIN-93 diberikan secara ad libitum. Pemberian pakan dilakukan selama 40 hari, kelompok STD diberikan pakan standar, kelompok KOL diberikan pakan tinggi lemak dan kelompok PLA diberikan pakan tinggi lemak yang didalam pakan tersebut telah di campurkan ekstrak PLA biji asam sebagai pengganti CMC. Masing-masing tikus diberi pakan sebanyak 20 gram. Pada hari ke 39 tikus dipuasakan untuk persiapan pengambilan darah, lalu pada hari ke 40 dilakukan pengambilan darah secara orbital plexus untuk mengetahui kadar glukosa darah tikus yang telah diberi perlakuan selama 40 hari.

\section{HASIL DAN PEMBAHASAN}

\section{Optimasi Ekstraksi Polisakarida Larut Air (PLA) Biji Asam Jawa}

Optimasi bertujuan untuk mendapatkan variable input terbaik dan mendapatkan respon rendemen dan kelarutan yang paling baik. Ringkasan batas atas dan batas bawah dari masing-masing variable dan respon terdapat pada Tabel 2. 
Potensi Ekstrak Polisakarida Larut Air (PLA) dari Biji Asam - Harijono, dkk Jurnal Pangan dan Agroindustri Vol. 9 No.2: 121-128, April 2021

Tabel 2. Kriteria variabel dan respon target

\begin{tabular}{lccc}
\hline \multicolumn{1}{c}{ Kriteria } & Target & $\begin{array}{c}\text { Batas } \\
\text { Bawah }\end{array}$ & Batas Atas \\
\hline Ukuran Partikel (mesh) & in range & 30 & 60 \\
Suhu Sonikasi $\left({ }^{\circ} \mathrm{C}\right)$ & in range & 40 & 60 \\
$\mathrm{pH}$ & in range & 5 & 9 \\
Rendemen $(\%)$ & maximize & 3.452 & 30.8262 \\
Kelarutan $(\%)$ & maximize & 16.8312 & 44.1089 \\
\hline
\end{tabular}

Pemilihan kriteria pada solusi optimal bertujuan mencari optimasi yang terbaik dari nilai batas atas dan batas bawah pada kelima variabel. Respon target pada penelitian ini adalah memperoleh nilai rendemen dan tingkat kelarutan yang tinggi. Optimasi ekstraksi yang diprediksi oleh program dikonfirmasi dan dibandingkan dengan hasil uji nyata. Perbandingan nilai prediksi dan hasil verifikasi terdapat pada Tabel 3.

Tabel 3. Nilai solusi aplikasi dan nilai verifikasi

\begin{tabular}{lccccc}
\hline \multicolumn{3}{c}{ Variabel Bebas } & \multicolumn{2}{c}{ Respon } \\
\hline & $\begin{array}{c}\text { Ukuran } \\
\text { Partikel } \\
\text { (mesh) }\end{array}$ & $\begin{array}{c}\text { Suhu } \\
\text { Sonikasi } \\
\left({ }^{\circ} \mathbf{C}\right)\end{array}$ & pH & Rendemen (\%) & Kelarutan (\%) \\
& 44.45 & 60.00 & 5.10 & 30.82 & 43.48 \\
\hline Prediksi & 44.45 & 60.00 & 5.10 & $30.44 \pm 1.28$ & $43.30 \pm 0.78$ \\
Verifikasi & & & 0.65 & 0.72 \\
T test (P-value) & & & & ts $^{*}$ & ts $^{*}$ \\
\hline
\end{tabular}

*ts: tidak signifikan

Software memberikan solusi optimum pada proses ekstraksi dengan kriteria ukuran partikel 44.454 mesh, suhu sonikasi $60^{\circ} \mathrm{C}$ dan $\mathrm{pH}$ 5.1. Nilai $p$-value $T$-test anatar prediksi dan verifikasi adalah tidak signifikan, sehingga tidak ada perbedaan anatar nilai prediksi dan verifikasi.

\section{Potensi Optimasi Ekstrak PLA Biji Asam Sebagai Kontrol Berat Badan dan Glukosa darah.}

Rerata Konsumsi Pakan

Nilai rerata konsumsi pakan oleh tikus terdapat pada Gambar 1. Gambar 1 menunjukkan bahwa konsumsi pakan antara kedua kelompok tikus tidak signifikan. Rerata nilai absolut konsumsi pakan, dari yang tertinggi sampai terendah, berturut-turut adalah tikus kelompok KOL, PLA, dan Standar

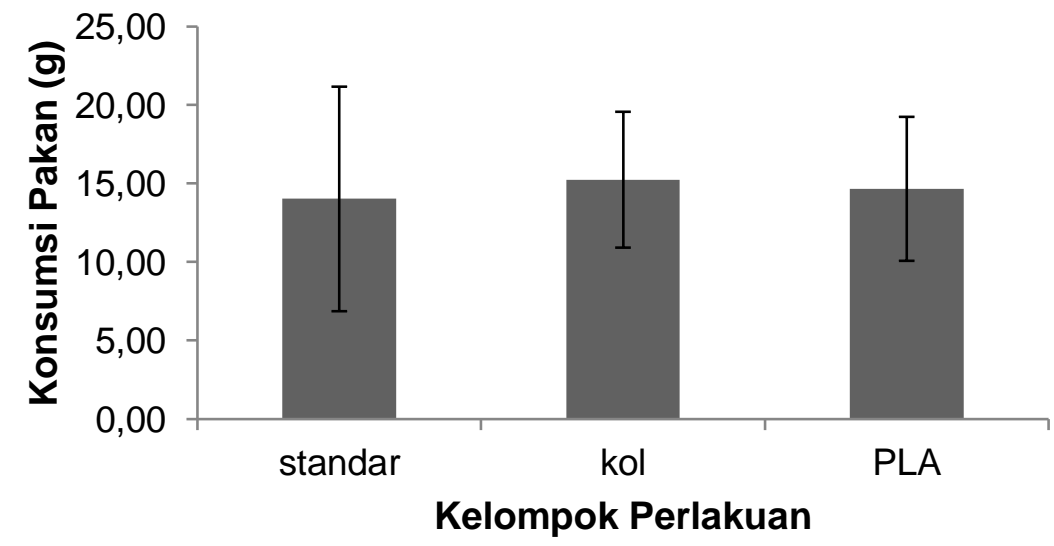

Keterangan: STD = Standar; KOL = kolesterol; PLA = Ekstrak kasar PLA

Gambar 1. Grafik Rata-Rata Konsumsi Pakan Oleh Tikus 
Lemak hewan yang digunakan untuk pembuatan pakan, selain Standar, mempunyai rasa dan aroma yang gurih yang diduga disukai tikus. Konsumsi pakan tikus kelompok PLA cenderung sedikit lebih rendah daripada tikus kelompok KOL. Penambahan ekstrak kasar PLA biji asam pada pakan tinggi lemak diduga dapat memberikan rasa kenyang lebih lama. Menurut Salarbashi et al, (2018), komponen polisakarida biji asam berfungsi sebagai dietary fiber yang dapat memberikan rasa kenyang lebih lama.

\section{Rerata Peningkatan Berat Badan}

Pengamatan BB bertujuan untuk mengetahui pengaruh perbedaan pemberian pakan isoprotein tetapi non-isokalori terhadap BB tikus. Tren kenaikan berat badan terdapat pada Gambar 2.

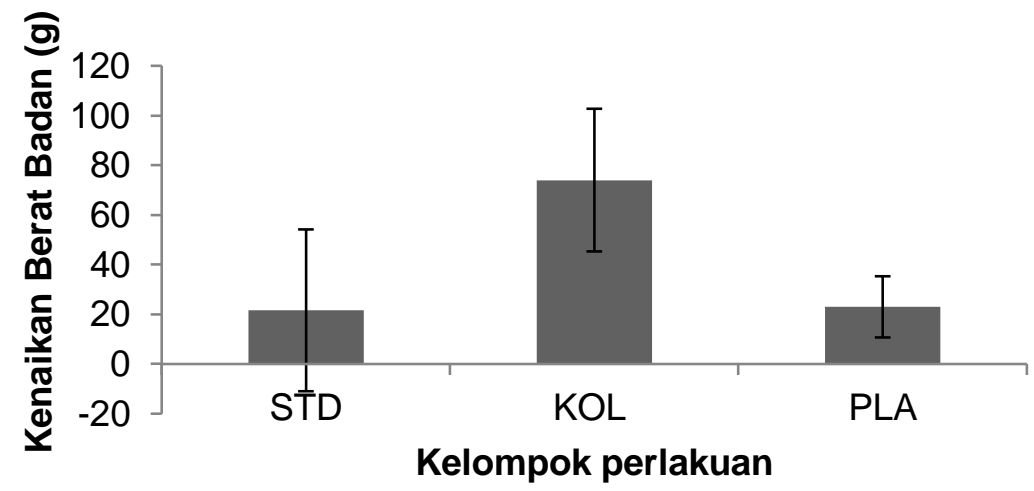

\section{Keterangan: STD = Standar; KOL = kolesterol; PLA = Ekstrak kasar PLA Gambar 2. Rata-rata kenaikan BB tikus}

Rata-rata bobot tikus pada masing-masing kelompok telah masuk dalam kategori obesitas. Menurut Rini et al, (2018) badan pada tikus usia 4-5 bulan dinyatakan obesitas apabila memiliki berat badan $>250$ gram. Tikus kelompok KOL merupakan kelompok tikus dengan penambahan berat badan paling tinggi dan berbeda nyata dengan kelompok lainnya. Hal ini dikarenakan komponen pada pakan yang tinggi kandungan lemak. Pemberian pakan yang juga tinggi lemak, menghasilkan pertambahan BB yang lebih rendah daripada KOL pada tikus kelompok PLA. Data menunjukkan bahwa tingkat konsumsi pakan rerata antar kelompok tidak berbeda secara nyata.

Adanya ekstrak PLA biji asam pada pakan memberikan rasa kenyang lebih lama sehingga tikus tidak banyak mengkonsumsi pakan dan berat badan tidak terlalu tinggi, hal ini terbukti dari perubahan berat badan tikus yang tidak terlalu banyak. Serat larut air merupakan polisakarida yang memiliki sifat pembentuk gel dan diketahui berperan dalam menurunkan kadar kolesterol. Serat dapat membuat makanan menjadi viskos sehingga makanan akan lambat dicerna oleh enzim, hal ini menyebabkan pengosongan lambung menjadi tertunda. Tertundanya proses pengosongan lambung ini menurunkan penyerapan nutrisi termasuk glukosa, sehingga glukosa darah menjadi lebih rendah atau kembali normal. Serat juga tidak dapat dicerna dan akan masuk ke dalam usus besar (Ding et al., 2017). Di dalam usus halus, serat larut air bersifat resisten terhadap hidrolisis namun mudah terfermentasi menjadi asam lemak rantai pendek (SCFA) oleh mikroba di usus besar. Proses fermentasi ini menginduksi hormon GLP-1, GIP, dan PYY yang dapat meningkatkan sensitivitas insulin.

Serat larut air (PLA) bersifat resisten terhadap hidrolisis saat berada di lambung (Zhang et al., 2018) sehingga tidak terserap di usus halus dan menyebabkan penundaan pengosongan perut. Senyawa ini akan masuk ke usus besar dan difermentasi menjadi asam lemak rantai pendek oleh mikroba di dalam usus besar. Produksi asam lemak rantai pendek seperti asam propionat terbukti mampu menurunkan sintesis kolesterol di hati dan berdampak pada penurunan kolesterol di dalam darah (Soliman, 2019). Sifat serat larut air yang mudah 
mengembang juga dapat mengikat dan mengadsorpsi garam empedu di dalam usus halus sehingga mendorong hati untuk memproduksi garam empedu dengan memanfaatkan kolesterol di dalam darah (Hua et al., 2017). Serat makanan juga meningkatkan glucagon-like peptide-1, yaitu hormon pada usus yang mengontrol rasa kenyang dan pengosongan lambung (Karl dan Saltzman., 2012), sehingga dapat menunda pengosongan lambung dan rasa kenyang yang lama, meningkatkan sensitivitas insulin dan memodulasi glukosa dan oksidasi lipid (Williams et al., 2017). Serat juga dapat meningkatkan Bacteroidetes dan Actinobacteria yang dominan pada individu kurus dan mengurangi Firmicutes dan Proteobacteria yang dominan pada individu obesitas (Dahiya et al., 2017). Adanya PLA pada pakan menyebabkan kenaikan BB kelompok PLA menjadi cenderung jauh lebih rendah daripada kelompok lain yang diberi pakan tinggi lemak,

\section{Kadar Glukosa Darah}

Pengaruh perlakuan pakan terhadap kadar glukosa darah (post-test) tikus percobaan dapat dilihat pada Gambar 3

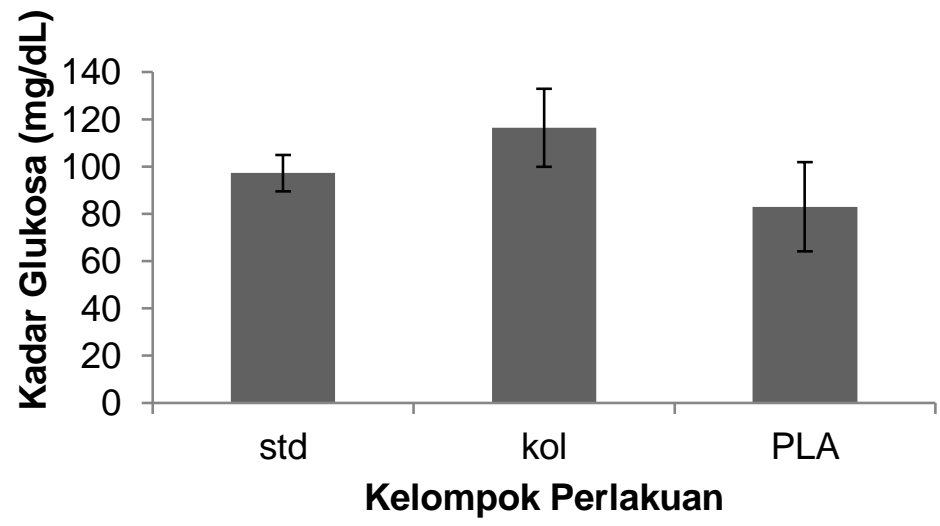

\section{Keterangan: STD = Standar; KOL = kolesterol; PLA = Ekstrak kasar PLA Gambar 3. Rata-rata Kadar Gula Darah Puasa Tikus (Post-Test)}

Pemberian pakan tinggi lemak dan kolesterol menunjukkan kadar gula darah tikus yang tertinggi pada kelompok KOL dan berbeda secara signifikan dibandingkan dengan tikus kelompok lainnya. Perlakuan penambahan PLA memberikan pengaruh signifikan pada kelompok KOL berpengaruh terhadap kadar gula darah tikus. Tikus kelompok KOL (kontrol positif) yang diberi pakan tinggi lemak dan kolesterol selama 40 hari menunjukkan kecenderungan mengalami hiperglikemia. Pemberian ekstrak kasar PLA biji asam ke dalam pakan diduga menghambat aksesibilitas enzim a-amilase menuju substratnya. Proses tersebut menyebabkan laju penyerapan glukosa dan kadar insulin dalam plasma menurun (Sole dan Srinivasan, 2012). Kadar glukosa puasa tikus yang diberi pakan mengandung PLA biji asam jauh lebih rendah daripada tikus kelompok KOL (tikus sakit). Menurut Kuru (2014), suplementasi ekstrak biji asam selama 7 dan 14 hari pada tikus diabetes dapat meningkatkan kadar glikogen pada hati dan otot. Enzim glukosa 6 fosfat, yang berperan mempertahankan kadar glukosa normal, dapat ditingkatkan aktivitasnya menggunakan ekstrak PLA biji asam. Selain itu ekstrak PLA biji asam juga mengandung beberapa biomolekul yang dapat membuat reseptor insulin peka dan merangsang sel induk pulau Langerhans di pankreas untuk mengembalikan kadar glukosa darah kembali ke tingkat normal (Kuru, 2014)

Ekstrak PLA biji asam merupakan serat larut air yang berfungsi sebagai sumber serat pada makanan. Serat ini dapat membentuk makanan menjadi lebih lengket atau viskos (membentuk gel) sehingga makanan tidak dapat dicerna oleh enzim yang terdapat dalam didalam pencernaan. Makanan yang telah berbentuk gel akan menjadi lambat dicerna sehingga dapat menunda pengosongan lambung (Saputro dan Estiasih, 2015). Lambatnya proses pencernaan ini menyebabkan terjadinya penurunan penyerapan nutrisi termasuk glukosa. Penurunan penyerapan glukosa menyebabkan kadar glukosa darah menjadi lebih 
rendah atau normal. Selain itu serat juga tidak dapat dicerna oleh enzim pencernaan sehingga serat akan masuk ke usus besar secara utuh (Saputro dan Estiasih, 2015). Serat yang masuk kedalam usus besar akan difermentasi oleh bakteri di usus besar dan membentuk SCFA (Short-Chain Fatty Acid). Pembentukan SCFA ini menginduksi sekresi hormon GLP-1 (Glucagon Like Peptide-1), GIP (Gastric Inhibitory Polypeptide), dan PYY (Petide YY) yang akan meningkatkan sensitivitas insulin dan menurunkan kadar glukosa dalam darah (Zhang et al., 2018).

\section{SIMPULAN}

Pemberian ekstrak kasar PLA biji asam dalam pakan pada kelompok tikus PLA berpengaruh signifikan pada penurunan glukosa tikus obesitas. Pemberian ekstrak PLA ini sangat efektif untuk menurunkan kadar glukosa darah tikus dan mengendalikan hiperglikemia secara efektif.

\section{UCAPAN TERIMAKASIH}

Ucapan terimakasih disampaikan kepada Fakultas Teknologi Pertanian Universitas Brawijaya yang telah memberikan dana untuk melaksanakan penelitian ini, dan kepada lbu Siti Narsito Wulan yang telah menyediakan sub-unit laboratorium untuk pengujian in vivo ditengah pandemic covid19 ini

\section{DAFTAR PUSTAKA}

Alpizar-Reyes, E., Carrillo-Navas, H., Gallardo-Rivera, R., Varela-Guerrero, V., AlvarezRamirez, J., \& Pérez-Alonso, C. (2017). Functional properties and physicochemical characteristics of tamarind (Tamarindus indica L.) seed mucilage powder as a novel hydrocolloid. Journal of Food Engineering, 209, 68-75. https://doi.org/10.1016/j.jfoodeng.2017.04.021

Azad, S. (2018). Tamarindo - Tamarindus indica. In Exotic Fruits Reference Guide (pp. 403408). Bangladesh: Elsevier Inc. https://doi.org/10.1016/B978-0-12-803138-4.00055-1

Benkeblia, N. (2014). Polysaccharides Natural Fibers in Food and Nutrition (N. Benkeblia, ed.). New York: CRC Press Taylor and Francis Group.

Dahiya DK, Puniya M, Shandilya UK, Dhewa T, Kumar N, Kumar S, Puniya AK., \& Shukla P. (2017). Gut Microbiota Modulation and Its Relationship with Obesity Using Prebiotic Fibres and Probiotics: A Review. Front. Microbiol., 8, 563.

Ding, Q., Nie, S., Hu, J., Zong, X., Li, Q., \& Xie, M. (2017). In vitro and in vivo gastrointestinal digestion and fermentation of the polysaccharide from Ganoderma atrum. Food Hydrocolloids, 63, 646-655. https://doi.org/10.1016/j.foodhyd.2016.10.018

Karl JP, \& Saltzman E. (2012). The Role of Whole Grains in Body Weight Regulation. Adv. Nutr. 3, 697-707

Kuru, P. (2014). Tamarindus indica and its health related effects. Asian Pacific Journal of Tropical Biomedicine, 4(9), 676-681. https://doi.org/10.12980/APJTB.4.2014APJTB2014-0173

Hua, X., Xu, S., Wang, M., Chen, Y., Yang, H., \& Yang, R. (2017). Effects of high-speed homogenization and high-pressure homogenization on structure of tomato residue fibers. Food Chemistry, 232, 443-449. https://doi.org/10.1016/j.foodchem.2017.04.003

Mota C., Márlon D., Sousa E., Brito D., Regina S., \& Ferreira S. (2020). Industrial Relevance of Tamarindus indica L. by-Products as Source of Valuable Active Metabolites. Innovative Food Science and Emerging Technologies, 66. https://doi.org/10.1016/j.ifset.2020.102518

Rini, C., Putri, H., \& Sunaryati, T. (2018). Pengaruh Ekstrak Tamarindus Indica Terhadap Kenaikan Berat Badan Pada Tikus Rattus novergicus yang Diberi Diet Obesitas. Jurnal IImiah Kedokteran Wljaya Kusuma, 6(1), 1-7.

Salarbashi D, \& Tafaghodi M. (2018). An Update On Physicochemical And Functional Properties Of Newly Seed Gums. International Journal of Biological Macromolecules, 
119, 1240-1247. https://doi.org/10.1016/j.ijbiomac.2018.06.161

Saputro, P. S., \& Estiasih, T. (2015). Pengaruh Polisakarida Larut Air (PLA) Dan Serat Pangan Umbi-Umbian Terhadap Glukosa Darah: Kajian Pustaka. Jurnal Pangan Dan Agroindustri, 3(2), 756-762.

Setyaningsih, I., Bintang, M., \& Madina, N. (2015). Potentially Antihyperglycemic from Biomass and Phycocyanin of Spirulina fusiformis Voronikhin by in Vivo Test. Procedia Chemistry, 14, 211-215. https://doi.org/10.1016/j.proche.2015.03.030

Sole, S. S., \& Srinivasan, B. P. (2012). Aqueous extract of tamarind seeds selectively increases glucose transporter-2, glucose transporter-4, and islets' intracellular calcium levels and stimulates $\beta$-cell proliferation resulting in improved glucose homeostasis in rats with streptozotocin-induce. Nutrition Research, 32(8), 626-636. https://doi.org/10.1016/j.nutres.2012.06.015

Soliman G A. (2019). Dietary Fiber, Atherosclerosis, and Cardiovascular Disease. Nutrients. 11: 1155

Williams BA., Grant LJ., Gidley MJ., \& Mikkelsen D. (2017).Gut Fermentation of Dietary Fibres: Physico-Chemistry of Plant Cell Walls and Implications for Health. Int. J. Mol. Sci., 18, 2203.

Zhang L, Liu Y, Ke Y, Liu Y, Luo X, Li C, Zhang Z, Liu A, Shen L, Chen H, Hu B, Wu H, Wu W, Lin D, \& Li S. (2018). Antidiabetic Activity of Polysaccharides from Suillellus Luridus in Streptozotocin-Induced Diabetic Mice. International Journal of Biological Macromolecules, 119, 134-140. https://doi.org/10.1016/j.ijbiomac.2018.07.109 